\title{
Effects of Peer Tutoring to the Learning Outcomes in Exponential Expressions of Grade 8 Students
}

\author{
Helmar G. Ycong \\ Department of Teacher Education, Visayas State University, Baybay City, Leyte, Philippines, \\ hgycong@vsu.edu.ph \\ Bayron S. Barredo \\ Department of Teacher Education, Visayas State University, Baybay City, Leyte, Philippines \\ bayron.barredo@vsu.edu.ph

\section{Leo A. Mamolo*} \\ *VSU Integrated High School, Visayas State University, Baybay City, Leyte, Philippines, \\ leo.mamolo@vsu.edu.ph
}

\begin{abstract}
Achieving the learning outcomes set for the classroom is the main goal of instruction. Todays' teachers utilize various methods to achieve optimum learning for the students. This study investigated the effect of peer tutoring strategy on the students' achievement in solving exponential expressions. It also determined the students' persistent errors in solving given exponential expressions. This study employed a quasi-experimental design and two intact classes randomly assigned to an experimental and control group. A validated 10-item test $(\alpha=.75)$ was utilized as the main instrument. Results revealed that students in the peer tutoring group performed better than in the lecture group. Moreover, the peer tutoring strategy significantly improved the learning outcomes of students in the experimental group. It is recommended that peer tutoring strategy may be used by mathematics teachers to improve their students' performance in the subject matter. Implications address the need to explore other teaching strategies suited for students in the Mathematics classroom.
\end{abstract}

Keywords: exponential expressions, peer tutoring strategy, experimental research, $K$ to 12 curriculum

\section{ABSTRAK}

Mencapai hasil belajar yang ditetapkan untuk kelas adalah tujuan utama dari instruksi. Guru saat ini menggunakan berbagai metode untuk mencapai pembelajaran yang optimal bagi siswa. Penelitian ini menyelidiki pengaruh strategi tutor sebaya terhadap prestasi siswa dalam memecahkan ekspresi eksponensial. Ini juga menentukan kesalahan persisten siswa dalam memecahkan ekspresi eksponensial yang diberikan. Penelitian ini menggunakan desain kuasi-eksperimental dan dua kelas utuh secara acak ditugaskan ke kelompok eksperimen dan kontrol. Sebuah tes 10-item divalidasi $(\alpha=0,75)$ digunakan sebagai instrumen utama. Hasil penelitian menunjukkan bahwa siswa dalam kelompok tutor sebaya tampil lebih baik daripada di kelompok kuliah. Selain itu, strategi peer tutoring secara signifikan meningkatkan hasil belajar siswa pada kelompok eksperimen. Direkomendasikan agar strategi tutor sebaya dapat digunakan oleh guru matematika untuk meningkatkan kinerja siswa dalam materi pelajaran. Implikasi membahas kebutuhan untuk mengeksplorasi strategi pengajaran lain yang cocok untuk siswa di kelas Matematika.

Kata kunci: Ekspresi Eksponensial, Strategi Tutor Sebaya, Penelitian Eksperimental, Kurikulum K 12

\section{INTRODUCTION}

Over the past decades, research revealed students' declining performance in mathematics subject (Stokke, 2015; Wijsman, et. al., 2016). As indicated in the Programme for International Student Assessment (PISA) 2018 results, Filipino students obtained an average of 353 points in Mathematical Literacy which is considered significantly lower than the OECD average (489 points) and was classified as below Level 1 proficiency (Department of Education, 2019). This result made 
the Philippines placed at the bottom among the participating ASEAN countries in PISA 2018. Moreover, the National Achievement Test (NAT) results in Mathematics from school years 2014$2015,2015-2016$, and 2016-2017 showed a decrease of mathematics performance from $69.71 \%$ to $34.75 \%$ for Grade 6 pupils and from $47.37 \%$ to $37.30 \%$ for Grade 10 students (Philippine Statistics Authority, 2019). With these, Mamolo and Sugano (2020) recommended appropriate educational interventions to improve students' learning. Thus, various teaching techniques were utilized in the Mathematics classroom with the aim of improving students' performance. One of those strategies is the use of peer tutoring in instruction. As shown in several researches, the peer tutoring strategy is a useful tool in improving student's academic performance in Mathematics (Chu, Chen, \& Tsai, 2017; Topping, Campbell, Douglas, \& Smith, 2003; Mayfield \& Vollmer, 2007; Tsuei, 2014; and Nawaz \& Rehman, 2017).

Peer tutoring is an instructional strategy that consists of student partnerships, linking high achieving students with lower achieving students or those with comparable achievement, for structured reading, science, and math study sessions (Batz et. al., 2015; Bellen \& Jomoc, 2017; Fuchs, et. al., 2002; Rohrbeck et. al., 2003). Pieces of researches have shown the benefits of peer tutoring to the students. The use of cooperative learning structures increases social motivation and engages students to achieve classroom goals. According to Bellen and Jomoc (2017), this strategy is more effective to a) students in grades $1-3$; b) urban settings; c) low socio-economic areas; d) minority students; e) school-wide prevention programs; and f) when students controlled tutoring sessions. This strategy was also employed in improving students' learning outcomes.

Learning outcomes is an expression of knowledge, skills, attitudes, and habits of mind that students take with them from a learning experience (Suskie, 2009). Along with this, students are expected to build a strong conceptual understanding of the class's skill. i.e., understanding and interpreting concepts and the relations between concepts (Arslan, 2010). Prior knowledge makes it easy for them to process and use new information related to that topic (Booth, 2011). In some cases, when support is limited, this information processing leads them to misconception. For some, it is not wrong thinking but rather a concept or a local generalization that the learners made and maybe a natural stage of development (Askew \& William, 2001). Students' misconception on mathematics subject and its concepts is one factor that keeps their learning outcomes low.

Sources of misconception were varied. These can be teacher-related and student-related factors (Liang \& Wood, 2005; Muzangwa \& Chifamba, 2012; Ramazan, 2010). For example, problem structures such as comparing exponents, especially when a decimal number is used as a base and a natural number, are used as a power (Ramazan, 2010), and lack of higher-order thinking skills (Liang \& Wood, 2005) were some misconceptions. One of the least learned topics is exponential expressions. There are recurring problems about the student's way of solving exponential expressions, although they were already given the necessary laws governing how to solve or manipulate it. Moreover, exponential expressions and logarithmic functions have been considered central concepts for many college and university mathematics; this includes algebra, differential equations, trigonometry, pre-calculus, calculus at large, and complex analysis (Denbel, 2019). However, despite being essential mathematical concepts, not much research has been done on 
students' learning difficulties and understanding of exponents. Christou et.al. (2007), as cited in Denbel (2019), highlights the need for studying exponents to gain knowledge about secondary school students' mental constructions. In most cases, students just memorize the rules of exponents without understanding the concepts. Furthermore, in his study, Ramazan (2010) stated that children blindly apply the prototype concept rules to other exponents, and thus the process turns into an algorithm and leads to errors. That's why, they may find it difficult to manipulate and correctly use the rules while moving from arithmetic to algebra. This study is realized given the fact the students only memorize the concepts on exponential expressions leading them to misunderstand higher concepts on Algebra. The data showing the effectiveness of peer tutoring strategy in the classroom is also the main reason why this study is performed. Thus, this aimed to determine the effects of peer tutoring on the students' learning outcomes in exponential expressions. Specifically, it sought answers to the following.

1. What is the level of students' learning outcomes in exponential expressions before and after the experiment utilizing the peer tutoring strategy?

2. Is there a significant increase in students' learning outcomes in solving exponential expressions using peer tutoring?

3. Is there a significant difference in students' learning outcomes in solving exponential expressions between the lecture and peer tutoring groups?

4. What are students' persistent errors in solving exponential expressions?

\section{METHOD}

\section{Research Design}

This study utilized a pre-post-test quasi-experimental research design. According to Cook and Campbell (1979), a quasi-experimental research is similar to experimental research but is not true experimental research. The independent variable is manipulated but participants are not randomly assigned to conditions or orders of conditions. The control group was subjected to lectures, while the experimental group utilized the peer tutoring approach in solving exponential expressions. This design was employed to determine the significant difference in students' learning outcomes between the lecture and peer tutoring groups in solving exponential expressions.

\section{Study Group}

The respondents involved 253 students. They were the Grade 8 students of S.Y. 2014-2015 of the selected secondary schools in Baybay City Division. Simple random sampling was utilized in the determination of the participating schools. In each chosen school, two sections were utilized as control and experimental groups. There were 141 students in the four control groups, and a total of 112 students in the four experimental groups. The treatment was conducted in each school for one (1) hour. The first 10 minutes were allocated for the conduct of pre-test. 35 minutes was devoted to the conduct of peer tutoring strategy. Afterwards, the next 10 minutes were spent for the post-test. The last 5 minutes was used for the retrieval of the students' papers and for the dismissal of the class.

\section{Study Site}


This study was conducted in four public junior high schools of Baybay City Division, Baybay City, Leyte, namely; Caridad NHS, Baybay NHS, Plaridel NHS, and VSU Laboratory High School. Baybay City is located in the Eastern part of the Visayas Region in Central Philippines. Before conducting the study, a permission letter from the Baybay City Division Superintendent was secured. After the approval, the researchers distributed copies to the principals and the section advisers of the student participants.

\section{Data Collection Tool}

In collecting the data, a validated and pilot tested 10-item short-answer test on solving exponential expressions was utilized. This was employed in determining the students' level of learning outcomes in exponential expressions. Two Mathematics experts validate the said instrument, and it was pilot-tested to chosen Grade 8 students. The questionnaire got a Cronbach's alpha of 0.75 , indicating the internal consistency of the questions.

The learning outcomes of the students were based on the point percentage they got on the 10 -item test. It was also described into levels stipulated by the Department of Education. Table 1 presents the levels of proficiency under the $\mathrm{K}$ to 12 curriculum.

Table 1. Levels of Proficiency under the K to 12 Grading System

\begin{tabular}{ll}
\hline Level of Proficiency & Equivalent Numerical Value \\
\hline Beginning & $74 \%$ and below \\
Developing & $75 \%-79 \%$ \\
Approaching Proficiency & $80 \%-84 \%$ \\
Proficient & $85 \%-89 \%$ \\
Advanced & $90 \%$ and above \\
\hline
\end{tabular}

\section{Data Gathering Procedure}

The researcher conducted a 10-item short-answer test on solving exponential expressions wherein students are asked to provide their answers after each item. The indicators of their learning outcomes are evaluated based on the laws on exponents (e.g., Power of a Product, Product Rule, and Quotient Rule). A single point will be given for each correct answer. Otherwise, the students will not obtain a point. Moreover, the students' levels of proficiency were established by following the Levels of Proficiency under the K to 12 Grading System (see table 1). It was subjected to an expert review and pilot testing ( $\alpha=.75)$. Four teachers were trained to facilitate the study. The teachers were selected based on the following criteria: he/she must have at least 5 years of teaching experience in Mathematics, he/she must be a graduate of at least a bachelor's degree in secondary education major in Mathematics, and he/she must be teaching Grade 8 mathematics. The teachers underwent four hours of training to ensure uniformity of the implementation (Mayfield \& Vollmer, 2007) which was also based on the lesson plan developed by the researchers. These lesson plans served as the standard operating procedures for conducting or delivering lessons to the control and experimental groups. The lesson plan for the control group was centered on lectures, while the lesson plan for the experimental group utilized the peer tutoring approach in solving exponential expressions. In the 
control group, the teacher administered a pre-test, and the students checked their papers. Individual points were assigned in each item. While checking, the teacher corrected the students' mistakes using the answer key. Afterward, a post-test was conducted then let the students checked their papers.

In the experimental group, the teacher administered a pre-test and checked the students' papers. The teacher returned the paper without any corrections but reflected their scores. Individual points were assigned in each item. Students were grouped to analyze the errors they have committed. During the session, 15 minutes was allotted. Alegre et. al. (2019) have shown that shorter than 30 minutes of session yield positive results in their literature review. Afterward, a post-test was conducted then let the students checked their papers.

Lastly, the post-test process from the control group to theexperimental group aimed to determine significant difference in students' learning outcomes in solving exponential expressions between the lecture and peer tutoring approaches.

\section{Data Analysis}

After the data collection, data had been analyzed using SPSS Version 21.0. The researchers utilized averages, t-test, and descriptive analysis. T-tests were employed to determine a significant difference between a lecture and peer tutoring approach and a significant increase between the lecture group's pre and post-test. The students' common errors in solving exponential expressions were identified through descriptive analysis.

\section{RESULT AND DISCUSSION}

\section{Students' Learning Outcomes in Exponential Expressions Before and After the Experiment}

This study aimed to determine the effects of peer tutoring on the students' learning outcomes in exponential expressions. In the pre-intervention phase, both groups were identical in their learning outcomes; hence, the experiment was conducted. After the experiment, it was found out that students' learning outcomes in exponential expressions have increased.

Table 2. Comparison of Students' Learning Outcomes Before and After the Experiment

\begin{tabular}{lcccccc}
\hline & \multicolumn{3}{c}{ Before Peer Tutoring } & \multicolumn{3}{c}{ After Peer Tutoring } \\
\hline & $M$ & $S D$ & Level & $M$ & $S D$ & Level \\
Plaridel NHS & 3.20 & 2.06 & Beginning & 8.76 & 1.37 & Proficient \\
VSULHS & 7.94 & 2.30 & Developing & 9.52 & 1.20 & Advanced \\
Caridad NHS & 3.75 & 2.45 & Beginning & 7.83 & 1.80 & Developing \\
Baybay NHS & 3.90 & 2.63 & Beginning & 9.50 & 0.81 & Advanced \\
AVERAGE & 4.70 & 2.36 & Beginning & 8.90 & 1.30 & Proficient \\
\hline
\end{tabular}

Table 2 shows the Grade 8 students' proficiency in exponential expressions before and after the experiment using peer-tutoring strategy. Data revealed that before introducing the peer tutoring strategy, most of the students' learning outcomes fall in the "Beginning" level, with Plaridel NHS in the lowest rank $(M=3.20, S D=2.06)$. After they were introduced to the peer tutoring strategy, a notable increase in the learning outcomes was noted. Students from the two schools even got an 
"Advanced" level with VSULHS as the highest in rank $(M=9.52, S D=1.20)$. The data suggest that the peer-tutoring strategy increased students' learning outcomes in exponential expressions. Furthermore, the peer tutoring strategy helps students acquire the essential competency in solving problems involving exponential expressions.

This result supports the Department of Education (2012), emphasizing that the students' level of proficiency was developing level, which means that students possess the minimum knowledge and skills and core understandings. If learners do not have a deep understanding of the concept of an exponent, they encounter difficulties while doing the task because most of the questions require them to use their conceptual knowledge (Ramazan, 2010). However, the need for help is essential throughout the performance of authentic tasks achieving optimum learning. The results also affirm that of Mamolo (2019), wherein senior high school students "Fair" competency in General Mathematics, which included topics about functions, indicated that these learners have not yet mastered the education department's stipulated competencies. Moreover, out of the 15 learned competencies, six came from functions and their graphs, which need the idea of the exponential expressions as a pre-requisite skill (Mamolo, 2019a).

\section{Students' Learning Outcomes in Solving Exponential Expressions Using Peer Tutoring}

This study also aimed to determine a significant increase in students' learning outcomes in solving exponential expressions using peer tutoring. Table 3 presents the paired samples T-test on the significant increase in students learning outcomes before and after the experiment. Data highlighted a significant increase in the respondents' learning outcomes employing a peer tutoring strategy, $t(111)=-15.51, p=.000$. This shows that utilizing a peer-tutoring strategy improves the learning outcomes of students in the subject matter. This further explains that when students work in pairs or groups, a better learning outcome is achieved.

Table 3. The T-test Results on the Significant Increase of Students Learning Outcomes Before and

\begin{tabular}{lcccc}
\multicolumn{5}{c}{ After the Experiment } \\
\hline & Mean & $t$ & $D f$ & Sig (2-tailed) \\
\hline Pair 1 & & & & \\
Pretest-Posttest & -4.237 & -15.507 & 111 & $0.000^{* *}$ \\
\hline
\end{tabular}

The above results indicate that a peer tutoring program can be effective in raising learning outcomes in mathematics. Studies have shown the effectiveness of peer tutoring among students in various mathematics topics like discrete numbers (Campit et. al., 2015). Still, there is little evidence in the literature of studies in which peer tutoring combined into the context of solving exponential expressions. The results about peer tutoring are consistent with the study of Bellen \& Jomoc (2017), Campit et al., (2015), Chua \& Wood (2005) and Ullah, et al., (2018), suggesting that peer tutoring can advance learning outcomes among high school students. Similar findings suggest effective peer tutoring intervention for at-risk students (Bellen \& Jomoc, 2017; George, et al., 2015; Mayfield \& Vollmer, 2007; Morales, et al., 2016).

\section{Students' Learning Outcomes in Solving Exponential Expressions Between the Lecture and Peer Tutoring Groups}


This study also determined the significant difference in students' learning outcomes between the lecture and peer-tutoring strategies. Table 4 presents the independent sample T-test on the significant difference between a lecture and a peer-tutoring strategy. It is noted that there is a significant difference between lecture and peer-tutoring strategy $t(217)=-8.918, p=0.000$. Results indicate that compared to the traditional teaching method, utilizing a peer-tutoring strategy is a better means of improving students' learning outcomes $(M=9.05, S D=1.368)$. Moreover, results highlighted that introducing a peer-tutoring strategy in a Mathematics class gives students the opportunity to perform better and acquire the set learning competency. This also proves that optimum learning is achievable.

Table 4. The T-test Results on the Significant Difference between Lecture and Peer-Tutoring

\begin{tabular}{|c|c|c|c|c|c|c|}
\hline Group & $n$ & $M$ & $d f$ & $t$ & Sig & Mean Difference \\
\hline Lecture & 141 & 6.730 & 217 & -8.918 & $0.000^{* *}$ & 2.32 \\
\hline Peer Tutoring & 112 & 9.054 & & & & \\
\hline
\end{tabular}

Literature offers a plausible explanation of the results. Instructional practices that employ peer mediation are known to produce students' increased achievement (Gan \& Hong, 2010; Fantuzzo, King, \& Heller, 1992; Nawaz \& Rehman, 2017; Parkinson, 2009; Adekoya \& Olatoye, 2011), improved social competence (Greenwood, 2008), and developed positive mathematics selfconcepts (Tsuei, 2012; Moliner \& Alegre, 2020). In this study, peer tutoring occurs in a situation in which students communicate with peers to find the solution to the problem and possible error in their solution. Peers communicate in their comfortable means of communication - first language. Bernardo (2002) believed that first language advantage in mathematics problems "provides a somewhat explicit link between linguistic processing that leads to understanding and problem-solving processes."

A prevailing benefit of peer tutoring strategy is that it created academically positive peer support for the mentees. Morales et al., (2016) consider that the "peer" part of the peer-tutoring was so valuable. The researchers opined that as the "mentees discussed their newly formed relationships; it became evident that they now had a peer group to follow that was serious, committed, and focused on their academic goals" (Morales, et al., 2016). In peer tutoring that usually takes place within the classroom in which students working in pairs previously know each other, there is higher confidence in their peers (Alegre, et al., 2019). Moreover, students in peer tutoring groups displayed greater interest in learning mathematics and self-efficacy in mathematics than those who underwent lectures (Gan \& Hong, 2010). As their interests in Mathematics ignite using the peer tutoring strategy, they will eventually develop their mathematics self-efficacy, which helps improve their academic performance or achievement. The students also felt that they learned the topic in a greater depth than the material presented in the conventional manner, using the peer tutoring strategy (Evans, Flower, \& Holton, 2001). Also, students can work, overcome difficulties, talk to peers who have an impact on achievement, and increase the ability better to understand classes of peer tutors than the conventional ones (Rosdianwinata, Rifa'l, \& Nasrullah, 2019). Furthermore, students also Indomath: Indonesian Mathematics Education - Volume 4 / Issue 02 | 2021 
demonstrate different reasoning abilities in mathematics when paired with peers at different levels of ability (Tsuei, 2012). As they interact with their classmates in the peer tutoring group, they eventually create a dialogue that will eventually hone their higher-order thinking skills. It also helps them address their common errors in doing the assigned tasks. Thus, this scenario helps in increasing the academic achievement, especially to the mediocre and to the low-performing students (Nawaz \& Rehman, 2017).

\section{Students' Persistent Errors in Solving Exponential Expressions}

This study also presents the students' persistent errors in solving exponential expressions. Table 5 reveals that students have errors in the following concepts; dividing the exponents instead of subtracting it, adding the exponents instead of multiplying it, and multiplying the exponents instead of adding it. A similar observation was reported in other math topics students' common problems in math problems such as wrong representation, wrong computation and use of trial-and-error method, misrepresentation, forgotten formulas, and concepts (Sia, 2012).

Table 5. Students' Persistent Errors in Solving Exponential Expressions

\begin{tabular}{cll}
\hline Item No. & Law of Exponent Applied & Description of Error \\
\hline 1 & Quotient Rule & Dividing the exponents instead of subtracting \\
3 & Power of a Product & Adding the exponents instead of multiplying \\
4 & Product Rule & Multiplying the exponents instead of adding \\
5 & Quotient Rule & Dividing the exponents instead of subtracting \\
6 & Product Rule & Dividing the exponents instead of subtracting \\
7 & Power of a Product & Multiplying the exponents instead of adding \\
8 & Quotient Rule & Adding the exponents instead of multiplying \\
9 & Quotient Rule & Dividing the exponents instead of subtracting \\
10 & Power of a Product & Dividing the exponents instead of subtracting \\
\hline
\end{tabular}

Similar results were found in which understanding laws of exponents involving negative (-) was the root cause of students' errors and misconceptions. The basic exponential rules were associated with negativity either as not properly perceived of wrongly interpreted by the students (Denbel, 2019). It was recommended in the study that students need to develop first the basic concepts with an understanding of additive inverse and multiplicative inverse to develop a more abstract understanding of negative operations in an algebraic expression (Denbel, 2019). Moreover, Barcellos (2005) determined certain persistent errors made by secondary algebra students involving the misuse of the equal sign and the exponent's distributive laws. Barcellos (2005) categorized errors related to the distributive laws as either invalid or incomplete distribution and concluded that they were generally due to a careless error rather than an underlying misconception.

These results also confirm that of the Cangelosi, Madrid, Cooper, Olson, and Hartter (2013) study, in which the notion of negativity played a prominent role in most of the mistakes of committed by most of the students. As a result, they theorized that the root of these errors is a poor conception 
of additive and multiplicative inverses. On the other hand, in his study, Ramazan (2010) showed that when base and power are used in natural number form, students were highly successful in computing exponents. However, in comparing exponents, they showed difficulties, particularly when a decimal number is used as a base and a natural number is used as a power. This is because teachers limit themselves in using prototype concepts to exemplify how students should solve the exponential equations in an appropriate way, which is defined as using elements of natural number as a base and a power (Ramazan, 2010; Pitta-Pantazi, Christou, \& Zachariades, 2007). So when students are given different sets of items to answer that are not aligned with the given examples, they find it difficult to operate the exponential expression given to them. Meanwhile, in his findings, Ulusoy (2019) indicated that the achievement of students was low, particularly in the zero and negative exponents. He added that students made mistakes as repeated multiplication with natural numbers and poor conceptions of additive and multiplicative structures that generally originated from the definition of exponentiation. As a result, the students excessively applied the rules that are true of the other exponent expressions for positive integer exponents. Another important result from his research was that because of the identity element of addition or the absorbing element of multiplication, most of the students did not know the meaning of zero exponents due to different obstacles.

In addition, when undertaking operations with exponent expressions, students made various mistakes due to confusion with additive and multiplicative structures in the operations of exponential expressions. This recurring confusion leads the students to commit persistent errors in solving exponential expressions. Furthermore, the following levels of understanding exponents were identified in the research by Pitta-Pantazi, Christou, and Zachariades (2007): (1) Level 1: the interpretation of exponents by students is based on the idea of exponents symbolizing natural numbers.; (2) Level 2: students' process of acquiring knowledge is a systematic way of enriching the existing conceptual structures (By extending the use of the examples given by the teacher, students can compute exponents with negative numbers); and (3) Level 3: students do not only extend the examples given by the teachers, but they also restructure their thinking in order to compute and compare exponential expressions with roots, a notion that is quite different from the exponents with natural numbers. With these levels, one can observe a progression of students' development of conceptual understanding in solving exponential expressions. The teacher must follow these activities to ensure a gradual but meaningful acquisition and demonstration of the students' skills and knowledge in learning to operate the exponential expressions.

On the other hand, the use of peer tutoring as a classroom strategy in learning outcomes in exponential expressions was proven effective. An academic benefit was documented; peer tutoring may have a positive, worthwhile outcome as academic gains have been documented under any condition (Alegre et al., 2019). Dela Cueva (2012) suggested that math teachers should dwell not only on the teaching of the concepts but also on the study strategies to make the lesson more comprehensive.

\section{CONCLUSION}

This study shows peer tutoring can help in the cognitive capacities of students. Students who underwent peer tutoring sessions improved exam performance compared to those exposed to 
conventional teaching strategies. Eventually, the result led to increased performance in the class and suggests that peer tutoring can reduce the failure in the regular classroom setting. It is suggested to embed peer learning into the pedagogy and planning in individual curriculum areas to achieve maximum impact (Bellen \& Jomoc, 2017). While the study focused on the intact classroom, it is suggested to target at-risk students as they need more support to help struggling students to succeed. In this study, it is worth establishing the qualitative changes both tutors and tutees underwent in the process. Also, additional research is needed to confirm why students make these errors and understand how to help students develop both an operational and structural understanding of exponential expressions.

\section{REFERENCES}

Adekoya, Y., \& Olatoye, R. (2011). Effect of demonstration, peer-tutoring, and lecture teaching strategies on senior secondary school students' achievement in an aspect of agricultural Science. The Pacific Journal of Science and Technology, 12(1), 320-332

Alegre, F., Moliner, L. Maroto, A., \& Lorenzo-Valentin, G. (2019). Peer tutoring and mathematics in secondary education: Literature review, effect sizes, moderators, and implications for practice, Heliyon, 5(9), 1-8. https://doi.org/10.1016/j.heliyon.2019.e02491

Arslan, S. (2010). Traditional instruction of differential equations and conceptual learning. Teaching Mathematics and its Applications: An International Journal of the IMA, 29(2), 94-107. doi:10.1093/teamat/hrq001

Barcellos, A. (2005). Mathematical misconceptions of college algebra students. Unpublished dissertation. University of California.

Batz, Z., Olsen, B.J., Dumont, J., \& Dastor, F. (2015). Helping struggling students in introductory biology: a peer-tutoring approach that improves performance, perception and retention. $C B E$ Life Science Education, 14, 1-12. doi:10.1187/cbe.14-08-0120

Bellen, J. A., \& Jomoc, A. B. (2017). Supporting struggling grade 8 science students' motivation, participation and performance through peer-tutoring approach. Annals of Tropical Research, 39(1), 147-15.

Bernardo, A. B. I. (2002) Language and mathematical problem solving among bilinguals. The Journal of Psychology, 136(3), 283-297.

Booth, J. L. (2011). Why can't students get the concept of math?. Perspectives on Language and Literacy, 37(2), 31-35.

Campit, JB, Cayabyab, J. \& Galas, E. (2015). The effect of peer tutoring on achievement of students in discrete structures. Asia Pacific Journal of Multidisciplinary Research, 3(5), 8-12.

Cangelosi, R., Madrid S., Cooper, S., Olson, J., Hartter, B. (2013). The negative sign and exponential expressions: Unveiling students' persistent errors and misconceptions. The Journal of Mathematical Behavior, 32(1), 69-82. doi:10.1016/j.jmathb.2012.10.002

Chu, H., Chen, J., \& Tsai, C. (2017). Effects of an online formative peer-tutoring approach on students' learning behaviors, performance and cognitive load in mathematics. Interactive Learning Environments, 25:2, 203-219

Cook, T. D., \& Campbell, D. T. (1979). Quasi-experimentation: Design \& analysis issues in field settings. Boston, MA: Houghton Mifflin.

De Dios, A. (2013). The National Achievement Test in the Philippines. http://www. philippinesbasiceducation.us/2013/07/the-national-achievement-test-in.html. (Accessed: March 15, 2015.

Denbel, D. (2019). Students' difficulties of understanding exponents and exponential expressions. Department of Mathematics, Dilla University, P.O, Box 419 Dilla, Ethiopia.

Department of Education. (2012). DepEd Order No. 31, s. 2012. Policy guidelines on the implementation of grades 1 to 10 of the K to 12 basic education curriculum (BEC) effective school year 2012-2013.

Department of Education. (2019). PISA 2018 National Report of the Philippines. Retrieved on March 3, 2020 from https://www.deped.gov.ph/wp-content/uploads/2019/12/PISA-2018-PhilippineNational-Report.pdf 
Evans, W., Flower, J., and Holton, D. (2001). Peer tutoring in First-year undergraduate mathematics. International Journal of Mathematical Education in Science and Technology, 32(2), 161-173

Fantuzzo, J., King, J., and Heller, L. (1992). Effects of Reciprocal Peer Tutoring on Mathematics and School Adjustment: A Component Analysis. Journal of Educational Psychology, 84(3), 331339.

Gan, S., \& Hong, K. (2010). The Effectiveness of Peer Tutoring in the Teaching of Mathematics. MJLI, 7, pp. 113-132

George, M., Khazanov, L., \& McCarthy, C. (2015). Peer coaching of at-risk students in a remedial Mathematics course. Community College Journal of Research and Practice, 39(11), 10221038. doi: $10.1080 / 10668926.2014 .922133$

Greenwood, C. R. (2008). Classwide peer tutoring: Longitudinal effects on the reading, language, and mathematics achievement of at-risk students. Journal of Reading, Writing, and Learning Disabilities International: Overcoming Learning Difficulties. 7(2), 105-123.

Chua, B. L., \& Wood, E. (2005). Working with logarithms: Students' misconceptions and errors. The Mathematics Educator, 8(2), 53-70.

Fuchs, D., Fuchs, L. S., Mathes, P. G., \& Martinez, E. A. (2002). Preliminary evidence on the social standing of students with learning disabilities in PALS and non-PALS classrooms. Learning Disabilities Research \& Practice, 17(4), 205-215.

Mamolo, L. (2019). Analysis of senior high school students' competency in general Mathematics. Universal Journal of Educational Research, 7(9), 1938-1944. https://doi.org/10.13189/ujer.2019.070913

Mamolo, L. (2019a). Development of Digital Interactive Math Comics (DIMaC) for senior high school students in general Mathematics. Cogent Education, 6(1), 1689639. https://doi.org/10.1080/2331186X.2019.1689639

Mamolo, L., \& Sugano, S.G. (2020). Self-perceived and actual competencies of senior high school students in General Mathematics. Cogent Education, 7(1), 1779505, https://doi.org/10.1080/2331186X.2020.1779505

Mayfield, K. H. \& Vollmer, T. R. (2007) Teaching math skills to at-risk students using home-based peer tutoring. Journal of Applied Behavior Analysis, 40(2), 223-237

Moliner, L. and Alegre, F. (2020) Effects of peer tutoring on middle school students' mathematics self-concepts. PLoS ONE 15(4): e0231410. https://doi.org/10.1371/journal.pone.0231410

Morales E.E., Ambrose-Roman, A., \& Perez-Maldonado R. (2016). Transmitting success: Comprehensive peer mentoring for at-risk students in developmental math. Innovation in Higher Education, 41, 121-135, doi: 10.1007/s10755-015-9335-6

Mullis I.V., Martin M.O., Gonzalez E.J. \& Chrostowski, S.J. (2004). TIMSS 2003 International Mathematics Report. TIMSS \& PIRLS International Study Center.

Muzangwa J., \& Chifamba, P. (2012). Analysis of errors and misconceptions in the learning of calculus by undergraduate students. Acta Didactica Napocensia, 5(2), 1-10.

Nawaz, A., and Rehman, Z. (2017). Strategy of Peer Tutoring and Students Success in Mathematics: An Analysis. Journal of Research and Reflections in Education, Vol 11, No 1, pp 15-30

Parkinson, M. (2009). The effect of peer assisted learning support (PALS) on performance in mathematics and chemistry, Innovations in Education and Teaching International, 46:4, 381 392. DOI: $10.1080 / 14703290903301784$

Philippine Statistics Authority. (2019). 2019 Philippine Statistical Yearbook. Retrieved on May 9, 2021, from https://psa.gov.ph/sites/default/files/2019-PSY_1003.pdf

Pitta-Pantazi, D., Christou, C., and Zachariades, T. (2007) Secondary school students' levels of understanding in computing exponents. Journal of Mathematical Behavior, 26, 301-311

Ramazan, A. (2010). Eight Graders' Capabilities in Exponents: Making Mental Comparisons. Practice and Theory in Systems of Education, 5(1), 39-48.

Rahman F, Khalil J, Jumani N, Ajmal M, Malile S, \& Sharif M. (2011). Impact of discussion method on students performance. International Journal of Business and Social Science, 2(7), 84-94.

Rosdianwinata, E., Rifa'l, R., and Nasrullah, A. (2019). Implementation of peer tutor learning in improving students' mathematical understanding ability. International Seminar on Applied Mathematics and Mathematics Education. doi:10.1088/1742-6596/1315/1/012027

Sia A.R. (2012). Students' performance, error patterns and attitude toward solving word problems in algebra. Journal of Research, 12(2), 12-29.

Stokke, Anna, What to Do About Canada's Declining Math Scores? (May 27, 2015). C.D. Howe Institute Commentary 427, Available at SSRN: https://ssrn.com/abstract=2613146 or http://dx.doi.org/10.2139/ssrn.2613146 
Suskie L. (2009). Using assessment results to inform teaching practice and promote lasting learning. In: Joughin G. (eds) Assessment, Learning and Judgment in Higher Education. Springer, Dordrecht.

Topping, K., Campbell, J., Douglas, W. \& Smith, A. (2003). Cross-age peer tutoring in mathematics with seven- and 11-year-olds: influence on mathematical vocabulary, strategic dialogue and self-concept. Educational Research, 45(3), 287-308. DOI: 10.1080/0013188032000137274

Tsuei, M. (2012). Using synchronous peer tutoring system to promote elementary students' learning in mathematics. Computers \& Education, 58, 1171-1182.

Tsuei, M. (2014). Mathematics Synchronous Peer Tutoring System for Students with Learning Disabilities. Educational Technology \& Society, 17 (1), 115-127.

Ullah, I., Tabassum, R., \& Kaleem, M. (2018). Effects of peer tutoring on the academic achievement of students in the subject of biology at secondary level. Education Sciences, 8, 112. doi:10.3390/educsci8030112

Ulusoy, F. (2019). Serious obstacles hindering middle school students' understanding of integer exponents. International Journal of Research in Education and Science (IJRES), 5(1), 5269. Retrieved from ERIC database. (EJ1198050)

Wijsman, L.A., Warrens M.J., Saab, N., van Driel J.H., \& Westenberg, P. (2016). Declining trends in student performance in lower secondary education. European Journal of Psychological Education, 31, 595-612. 10.1007/s10212-015-0277-2 